${ }^{1} \mathrm{PhD}$, Scientific Researcher, Ankara Hacı Bayram Veli University

${ }^{2} \mathrm{PhD}$ Student, Department of Public Administration, Ankara Hacı Bayram Veli University

${ }^{3} \mathrm{MA}$, Research Fellow, Eurasian Research Institute

${ }^{4} \mathrm{PhD}$, Acting Associate Professor, Khoja Akhmet Yassawi International Kazakh-Turkish University

\title{
DEMOGRAPHICS OF KAZAKHSTAN: THE END OF ACTIVE GROWTH CYCLE
}

\section{Abstract}

The demographics of Kazakhstan is characterized by waves of increase and decline that occur periodically every 25-30 years. Since 2010, the share of deaths among working age population (from 15 to 60 years) dropped from 35.9 to 29.4. It is important to note that the number of emigrants keeps increasing every year since 2014. We can expect a rather significant decline of the current population growth rates, which are likely to drop below $1 \%$ per year in 3-5 years from now. The social and economic shape of the country changed radically. Conditions when economic signals work that allows to draw very essential conclusion were created: the mechanism of the market is started. In the market there was a situation when the prices regulate supply and demand, define movement of commodity streams, the competition nature, investment streams that already characterizes development of the modern period.

Keywords: Kazakhstan, demography, age of groups, number of births, emigrant.

\author{
А.А. Амирбек ${ }^{1}$, А.Ануарбекұлы ${ }^{2}$, Қ.Маханов ${ }^{3}$, М.Анламасова $^{4}$ \\ ${ }^{1} \mathrm{PhD}$, Ғылыми зерттеуші, Анкара Хаджы Байрам Вели университеті. \\ ${ }^{2} \mathrm{PhD}$ докторанты, Мемлекеттік басқару мамандығы, Анкара Хаджы Байрам Вели \\ университеті. \\ ${ }^{3}$ магистр, Ғылыми қызметкер, Еуразия ғылыми-зерттеу институты. \\ ${ }^{4} \mathrm{PhD}$, доиент м.а., Қ.А. Ясауи атындавы Хальққаралық қ̧азақ-түрік университеті
}

\section{ҚАЗАҚСТАННЫН ДЕМОГРАФИЯСЫ: ӨСУДІН БЕЛСЕНДІ ЦИКЛІН ТАЛДАУ}

\section{Аңдатпа}

Соңғы 25-30 жылда Қазақстанның демографиялық ахуалы өсу мен азаю кезеңдерінен өтті. 2010 жылдан бастап халық ішінде еңбекке жарамды (15-тен 60 жасқа дейін), алайда қайтыс болғандардың саны 35,9-дан 29,4-ке пайызға дейін төмендеді. Сонымен қатар 2014 жылдан бастап эмигранттардың саны жыл сайын артып барады. Алдағы 3-5 жылда халықтың ағымдағы өсу қарқыны төмендеуі мүмкін деп болжамдауға болады. Экономикалық сигналдар жұмыс істеп тұрған кезде жағдайлар жасалды, бұл өте маңызды қорытынды жасауға мүмкіндік береді: нарық тетігі іске қосылды. Нарықта бағалар сұраныс пен ұсынысты реттейтін, Тауар ағындарының қозғалысын, бәсекелестіктің сипатын, инвестициялық ағындарды анықтайтын жағдай қалыптасты, бұл қазіргі заманғы кезеңнің дамуын сипаттайды.

Түйін сөздер: Қазақстан, демография, жас топтары, туу саны, эмигрант.

Амирбек А.А. ${ }^{1}$, Ануарбекулы А. ${ }^{2}$, Маханов К. ${ }^{3}$, Анламасова M. ${ }^{4}$ 
${ }^{1} \mathrm{PhD}$, Научный исследователь, Анкара Хаджы Байрам Вели университет.

2 Докторант $\mathrm{PhD}$, Специальность «Государственное управление»,

Университет имени Анкара Хаджы Байрам Вели.

${ }^{3}$ Магистр, Научный сотрудник, Евразийский научно-исследовательский институт.

${ }^{\mathrm{PhD}}$, и.о. доцент, Международный казахско-турецкий университет имени Ходжи Ахмеда

Ясави

\title{
ДЕМОГРАФИЯ КАЗАХСТАНА: АНАЛИЗ АКТИВНОГО ЦИКЛА РОСТА
}

\begin{abstract}
Аннотация
Демографическая ситуация Казахстана характеризуется волнами роста и спада, которые периодически происходят каждые 25-30 лет. С 2010 года доля умерших среди трудоспособного населения (от 15 до 60 лет) снизилась с 35,9 до 29,4 процента. Несмотря на это, количество эмигрантов с 2014 года продолжает расти с каждым годом. Вкратце, можно ожидать довольно значительного снижения текущих темпов прироста населения через 3-5 лет. Были созданы условия, когда экономические сигналы работают, что позволяет сделать очень существенный вывод: запущен механизм рынка. На рынке сложилась ситуация, когда цены регулируют спрос и предложение, определяют движение товарных потоков, характер конкуренции, инвестиционные потоки, что уже характеризует развитие современного периода.
\end{abstract}

Ключевые слова: Казахстан, демография, возрастные группы, число рождений, эмигрант.

According to the latest data by the Committee on Statistics of Ministry of the National Economy of Kazakhstan, by July 1 of 2019 the population of Kazakhstan has reached 18,507,942, which is $0.61 \%$ growth since the begging of the year. Since 2006, Kazakhstan has seen a rapid demographic growth exceeding $1 \%$ per year and the data shows that this process continues. However, if we take the dynamics of the population change we can note signs of deceleration of the population growth and there are signs indicating that 2019 might well be the ending of this cycle.

The demographics of Kazakhstan experienced a sharp decline after 1989 due to emigration of population and drop of the birth rate caused by political changes and economic downturns after the collapse of USSR [Ministry of Economy and Budget Planning of Kazakhstan, 2014]. It was only by 2003 when population growth turned positive again and it took more than two decades for Kazakhstan to recover its population size of 1989.

Figure 1. Population growth rate in Kazakhstan. 


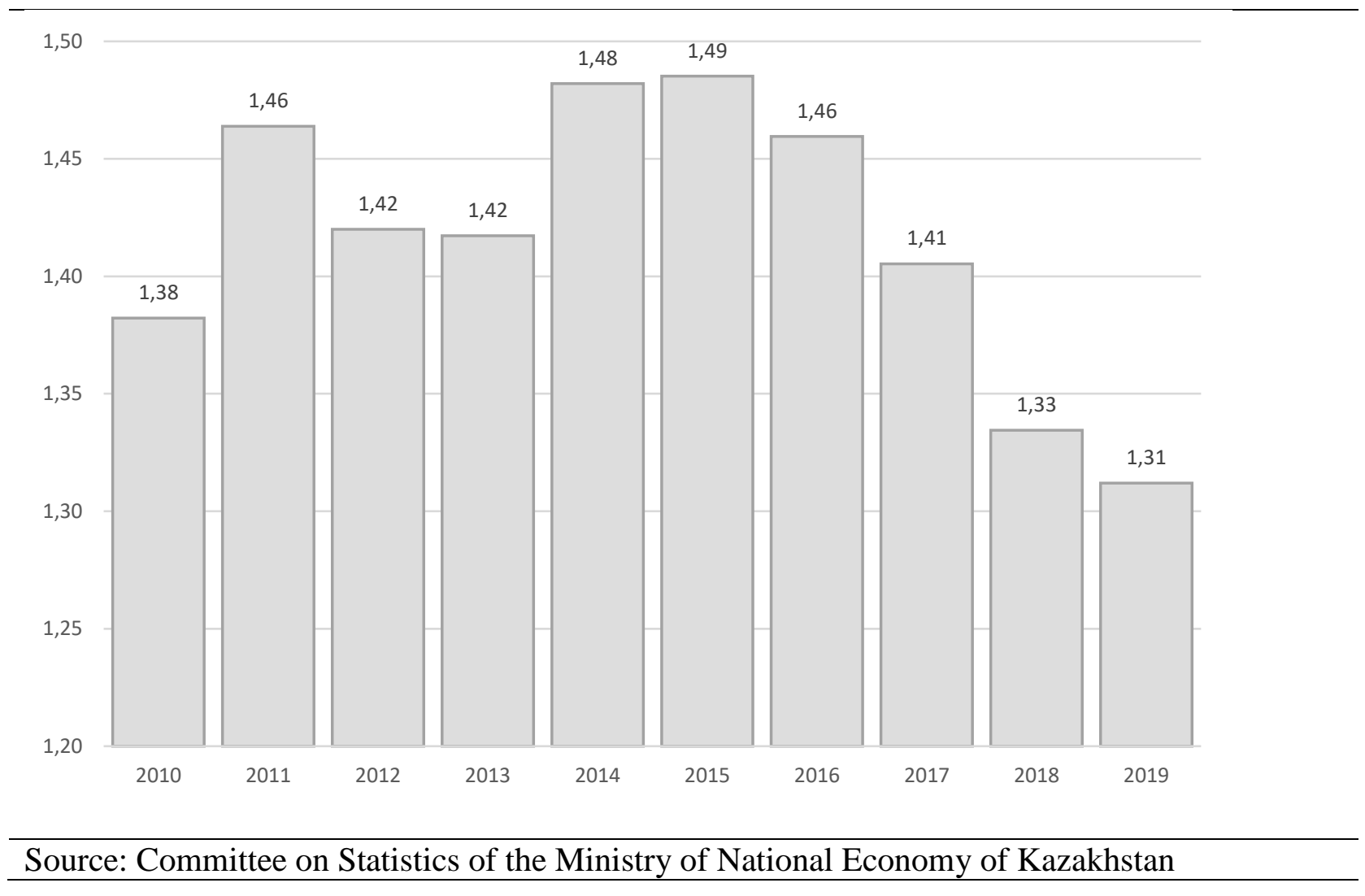

The period since 2006 has been marked by a rapid demographic growth and 2015 has been the peak of the growth cycle. We use the term "cycle" to describe the demographics of Kazakhstan because there are cyclical patterns that determine the demographic changes of the country. One of the easiest ways to detect these cyclical demographic patterns of the demographics in Kazakhstan is the age pyramid showing a distribution of population by different age groups. Looking at the current age pyramid, we can note that the current demographic expansion is largely caused by a previous demographic rise that took place right before the independence of Kazakhstan in 1991. Therefore, the demographics of Kazakhstan is characterized by waves of increase and decline that occur periodically every 25-30 years. In other words, the largest current cohort of population under 15 is the direct result of the demographic rise in late 1980s consisting of people that started to have their own children in the beginning of 2000s. Looking at the shape of the age pyramid, we can note that the current expansionary demographic cycle is finishing.

Another way of making a rough forecast of natural population change in the nearest future disregarding other factors is to look at the number of people of most reproductive age groups. In two major age groups of 20-24 and 25-29, which usually comprise the most reproductive population shares accounting for nearly $58 \%$ of the total number of births. Looking at the change of the absolute number of population aged from 20 to 29, we can note a rapid decline after 2014 when it peaked at 3.14 million people. Correspondingly, the number of births also peaked nearly at the same time reaching 400 thousand in 2016, which is expected to be the highest indicator of the current demographic cycle [365info.kz, 2018]. On the other hand, from Figure 3 we can also observe that the number of births and the size of the population between 20 and 29 do not match perfectly. The growing number of population cohort led to a proportionate increase of the number of births. However, although this part of the population started to shrink after 2014, the number of births still stay very high. The slight divergence between the population size that are currently in their 20s and the number of births reveals another very important factor that reveals itself in recent statistics, which is the shifting of the most intense reproductive age.

Figure 2. Age pyramid of Kazakhstan by the beginning of 2019 


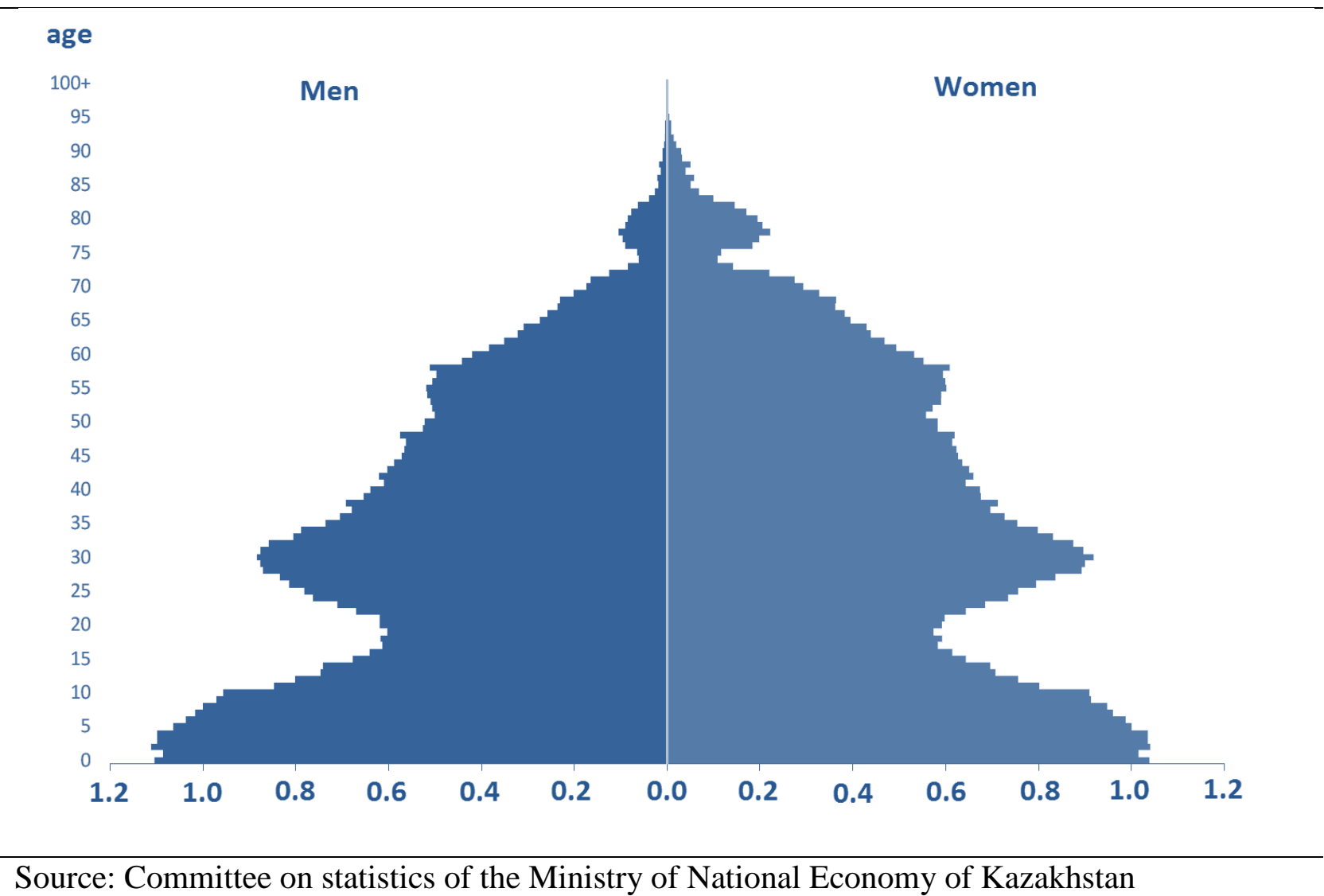

Source: Committee on statistics of the Ministry of National Economy of Kazakhstan

During the last couple of decades, there has been a gradual shift of the decision of childbirth by women towards later stages of their lives. As a result, nowadays more number of women give birth in their late twenties and early thirties than it was 15-20 year ago. Figure 4 provides a graphical illustration of this change.

Over the course of the last twelve years, the share of women giving birth at their early $20 \mathrm{~s}$ has shrunk from $33.8 \%$ to $25.4 \%$ whereas the percentage of those who decide to have children in their late 20s increased from $28.9 \%$ to $32.5 \%$. Moreover, higher shares of women postpone their childbirth decision to their 30 s so that women between 30 and 34 accounted for $24.1 \%$ of all births in 2018 compared to $18.6 \%$ in 2007 . Moreover, there is even an increase of the percentage of women giving birth in 35-39 age cohort from 9.4\% in 2007 to $11.7 \%$ in 2018. As a result of these transformations that took place in a very short period of time, currently, the age group of women from 25 to 29 is the leading narrow age cohort in terms of births. In 2008, a broader age group of women from 25 to 34 accounted for $56.6 \%$ of all births in Kazakhstan. Due to the increase of the share of the population with the highest reproductive indicators during the last 1015 years, the overall fertility rate increased from 2.60 in 2007 to 2.84 in 2018 . This is one of the main reasons explaining the recent rapid population growth.

Figure 3. Number of people in age group of 20-29 vs number of births 


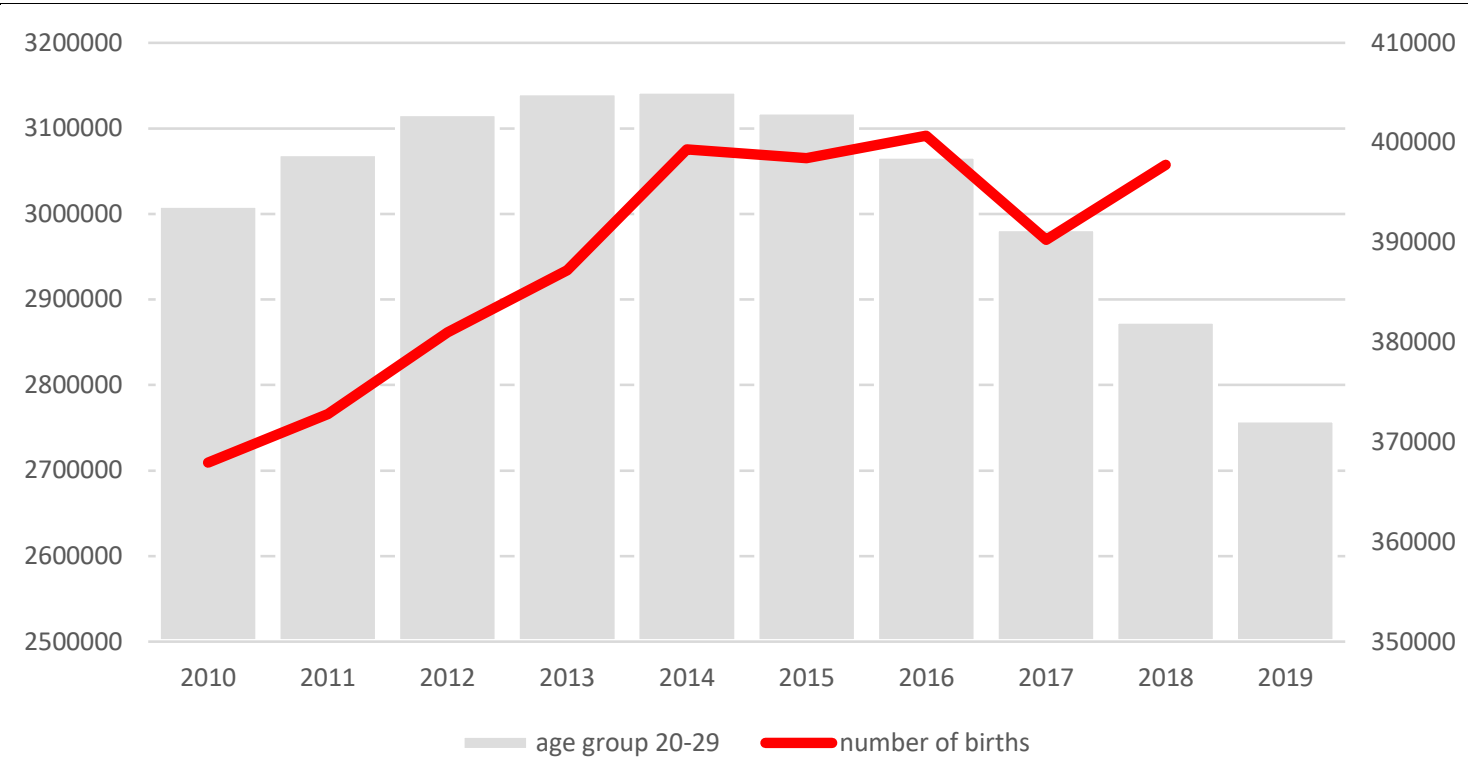

Source: Committee on statistics of the Ministry of National Economy of Kazakhstan

The growth part of the population is partially or totally offset by death rates. If we analyze the death rates in Kazakhstan over the last 10-15 year, we can also note some significant positive changes that contributed to the overall population growth [Aubakirova and Ualieva, 2017]. For instance, the overall death rates per 1,000 people has fallen from 8.97 in 2010 to 7.14 in 2018 . More importantly, since 2010, the share of deaths among working age population (from 15 to 60 years) dropped from 35.9 to 29.4. The overall average life expectance at birth during the same period of time increased from 68.45 to 73.15 . By looking at the current age pyramid, we can note that one of the largest age groups around 30 years were preceded by another population wave that is currently approaching to the age of 60 . Based on the statistics of the previous periods, we can expect a gradual rise in death rates in 3-5 years from now.

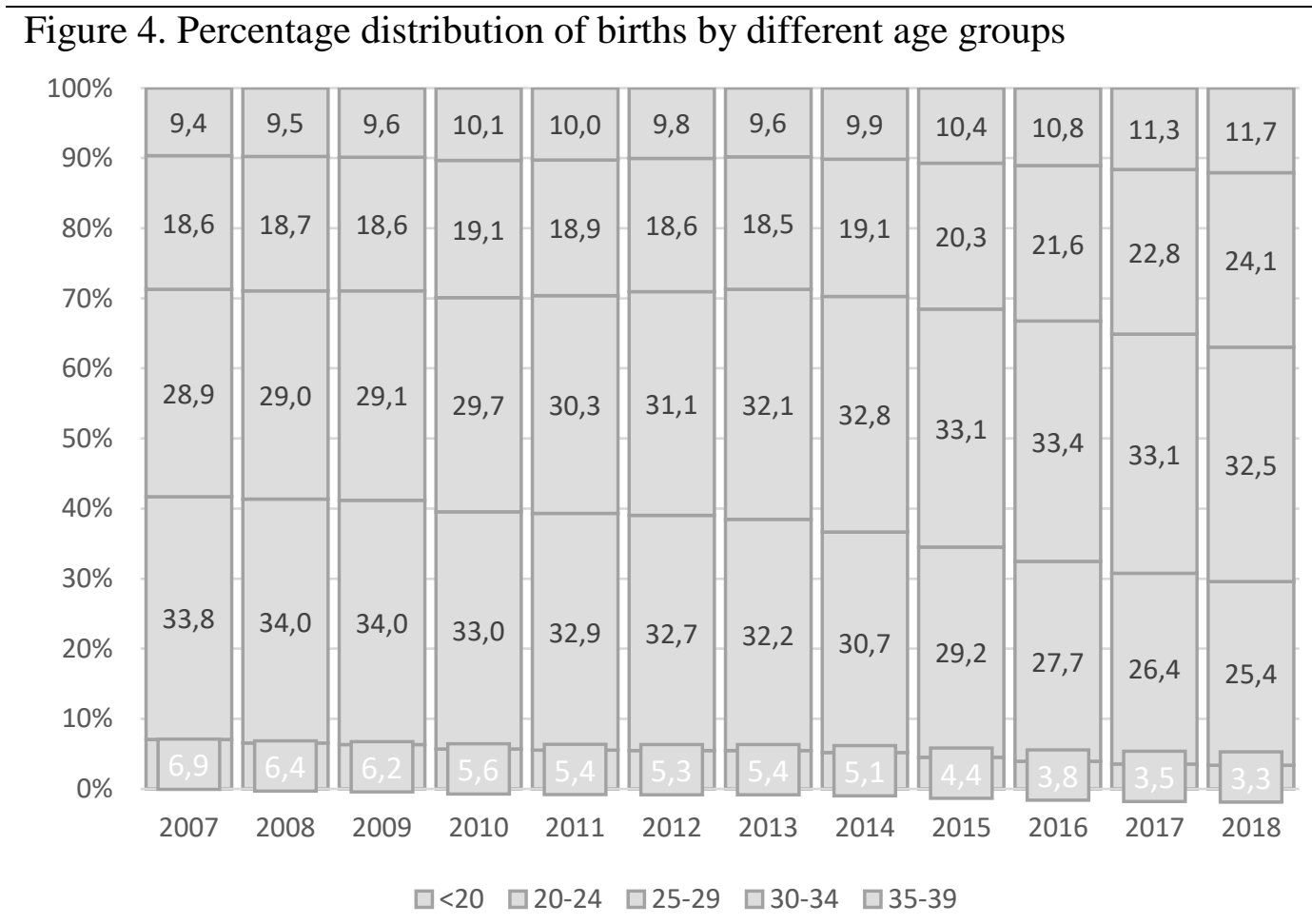

Source: Committee on statistics of the Ministry of National Economy of Kazakhstan 
Lastly, there is another pillar sustaining the demographics of any country, which is migration. In this regard, we have to admit that the situation has worsened considerably during the last five year. In 2018, the net migration presented a negative 29,121 people, which is the worst indicator since 2002. Although the net loss of population from emigration is still very low compared the natural reproduction of population and insufficient to produce considerable demographic effects [Simakova, 2019], it is important to note that the number of emigrants keeps increasing every year since 2014.

The recent data shows that throughout nearly 30 years of independence, the demographics of Kazakhstan has experienced drastic changes in terms of population growth rates. During the last 13 years, Kazakhstan's population has been showing a rapid growth of above $1 \%$ per year. This stands in stark contrast with 1990s, when its population was in fast decline. Dramatic changes of the natural population growth rates and current population pyramid suggest a clear cyclical pattern of demographic growth in Kazakhstan. The current cycle of demographic growth is based on several factors determining the natural population change. However, a brief analysis of these factors reveals that the current cycle of a rapid demographic growth is finishing. Consequently, we can expect a rather significant decline of the current population growth rates, which are likely to drop below $1 \%$ per year in 3-5 years from now. One of the main forces causing the demographic deceleration is the natural decrease of the birth rates due to smaller size of the most reproductive age groups 3-5 year from now. Moreover, a relatively large group of population is expected to enter the age group of above 60 years age suggesting a growth of death rates in the near future. On the other hand, factors like shifting reproductive age, longer life expectancy, gradually declining death rates in most of the age groups and varying migration patterns will ensure a smooth cyclical change in demographics of Kazakhstan.

\section{References:}

1. 365info.kz (2018). Kazakhstan will obviously have problems soon. Retrieved from https://365info.kz/2018/06/u-kazahstana-yavno-skoro-budut-problemy-politolog. Accessed on 14.01 .2020

2. Aubakirova Zh.S. and Ualieva S.K. (2017). Mortality of the population of Kazakhstan: historical and demographic aspect. Retrieved from https://articlekz. com/article/18101. Accessed on 14.01.2020

3. Committee on Statistics of the Ministry of National Economy of Kazakhstan (2019). Demographic Yearbook 2014-2018. Retrieved from http://old.stat.gov.kz/faces/wcnav_externalId /publications

Compilations?_afrLoop=5063365927745556\#\%40\%3F_afrLoop\%3D5063365927745556\%26_a df.ctrl-state\%3D47f0xkdhp_42. Accessed on 14.01.2020.

4. Committee on Statistics of the Ministry of National Economy of Kazakhstan (2019). Demographic Yearbook 2010. Retrieved from http://old.stat.gov.kz/ faces/wcnav_externalId /publications

Compilations

2011?_afrLoop=5321331399986163\#\%40\%3F_afrLoop\%3D5321331399986163\%26_adf.ctrlstate\%3D5rtagl29t_68. Accessed on 14.01.2020

5. Ministry of Economy and Budget Planning of Kazakhstan (2014). Demographic Forecast of the Republic of Kazakhstan: Main Trends, Challenges, Practical Recommendations. Retrieved from http://www.akorda.kz/upload/nac_komissiya_po_ delam_zhenshin/Демографическая\%20политика/4.2\%20pyc.pdf. Accessed on 14.01.2020. 6. Simakova, O. (2019). Emigration from Kazakhstan as an outflow of human capital. Retrieved from http://www.contur.kz/node/3656. Accessed on 14.01.2020. 
1. 365info.kz (2018). Жақын арада Қазақстанда проблемалар туындайтыны анық. Алынған https://365info.kz/2018/06/u-kazahstana-yavno-skoro-budut-problemy-politolog. өтініш берген күні 14.01.2020

2. Ж.С. Аубакирова, С. К. Уалиева (2017). Қазақстан халқының өлім-жітімі: тарихидемографиялық аспект. Алынған https://articlekz. com/article/18101. Өтініш берген күні 14.01.2020

3. Қазақстан Республикасы Ұлттық экономика министрлігінің Cтатистика комитеті (2019). 2014-2018 жылдардағы демографиялық жылнамасы. Алынған http://old.stat.gov.kz/faces / wcnav_externalid / Жарияланымдар жинағы?_afrLoop=5063365927745556\#\%40\%3F_afrLoop\%3D5063365927745556\%26_adf.ctrlstate\%3D47f0xkdhp_42. Өтініш берген күні: 14.01.2020.

4. Қазақстан Республикасы Ұлттық экономика министрлігінің Статистика комитеті (2019). 2010 жылғы демографиялық жылнамасы. Алынған http://old.stat.gov.kz/faces / wcnav_externalid / Жарияланымдар жсинағы 2011?_afrLoop=5321331399986163\#\%40\%3F_afrLoop\%3D5321331399986163\%26_adf.ctrlstate\%3D5rtagl29t_68. Өтініш берген күні 14.01.2020

5. Қазақстан Республикасы Экономика және бюджеттік жоспарлау министрлігі (2014). Қазақстан Республикасының демографиялық болжамы: негізгі үрдістер, проблемалар, практикалық ұсынымдар. Алынған http://www.akorda.kz/upload/nac_komissiya_po_delam_zhenshin / демографиялық\%20 саясат / 4.2\% 20rus.pdf. Өтініш берген күні: 14.01.2020.

6. Симакова О. (2019). Қазақстаннан көшіп кету адами капиталдың кетуі ретінде. Алынған http://www.contur.kz/node/3656. өтініш берген күні: 14.01.2020. 